Original Research Article

\title{
Analgesic activity of Alpinia galanga extract in mice models and TNF- alpha receptor computational docking analysis on its leads with pharmacokinetics prediction
}

\author{
K. R. Subash ${ }^{1}$, G. Francis Britto ${ }^{2 *}$, Katari Sudheer Kumar ${ }^{3}$, Amineni Umamaheshwari', \\ Vijaya Chandra Reddy Konda ${ }^{1}$, Bhanu Prakash G. ${ }^{1}$
}

${ }^{1}$ Department of Pharmacology, SVIMS-Sri Padmavathi Medical College for Women, SVIMS University, Tirupati, Andhra Pradesh, India

${ }^{2}$ Department of Pharmacology, IRT-PMC, Sanatorium (post), Perundurai, Erode, Tamilnadu, India

${ }^{3}$ Bioinformatics Centre, Department of Bioinformatics, SVIMS University, Tirupati517507, Andhra Pradesh, India

Received: 17 December 2017 Accepted: 11 January 2018

*Correspondence to:

Dr. G. Francis Britto,

Email: stbritto@hotmail.com

Copyright: (C) the author(s), publisher and licensee Medip Academy. This is an openaccess article distributed under the terms of the Creative Commons Attribution NonCommercial License, which permits unrestricted noncommercial use, distribution, and reproduction in any medium, provided the original work is properly cited.

\begin{abstract}
Background: Alpinia galanga is an ayurvedic herb recognized and used across many traditional medicine systems for its analgesic and anti-inflammatory activity. The present study scientifically validates the potential anti nociceptive action of ethanolic extract of Alpinia galanga by chemical, neurogenic and inflammatory nociception model in mice followed by identification of potential lead compound by computational analysis.

Methods: The assessment of anti nociceptive action is evaluated by Acetic acid induced abdominal constrictions and Formalin assay on ethonolic extract of Alpinia galanga, followed by 20 compounds with known chemical structure of Alpinia galanga is subjected to computational analysis to predict possible lead compound with desirable pharmacokinetic and drug like features.

Results: The percentage inhibition rate of Aspirin $(100 \mathrm{mg} / \mathrm{kg})$ was $82.15 \%$ compared to Alpinia galanga $(100 \mathrm{mg} / \mathrm{kg}) 19.63 \%$, $(200 \mathrm{mg} / \mathrm{kg}) 33.02 \%$ and $(400 \mathrm{mg} / \mathrm{kg}) \quad 57.13 \%$ by acetic acid induced abdominal constrictions antinociceptive mice model. Alpinia galanga $400 \mathrm{mg} / \mathrm{kg} \quad(71.70 \%)$ had comparable percentage inhibition of nociception to standard group indomethacin $(88.71 \%)$ in formalin induced nociceptive mice model. Among 20 compounds screened for pharmacokinetic and drug like features, Galanal B had the binding free energy -56.664 when compared to control compound 2AZ5-56.000.

Conclusions: The Alpinia galanga extract had significant anti nociceptive activity and followed by computational analysis of 20 compounds with known chemical structure predicted Galanal B as lead compound with best insilico pharmacokinetic and drug like features.
\end{abstract}

Keywords: Alpinia galanga, Formalin assay, Insilico, Nociception, QSAR

\section{INTRODUCTION}

Many herbal ingredients in combination or as single ingredient is used since ages as a remedy for pain. The herb
Alpinia galanga from Zingiberaceae family is very commonly seen as an Ayurvedic preparation for wider therapeutic application, importantly for painful inflammatory disorders. ${ }^{1}$ A. galanga is advocated to treat inflammatory disease like bowel inflammation and 
rheumatism with more than 2500 years history in Ayurvedic and Chinese medicine. Many studies on ginger has proven to exhibit prostaglandin suppression through inhibition of cyclooxygenase-1 (COX-1) and cyclooxygenase-2 (COX-2) thereby its application in inflammatory disease in arthritis was scientifically appreciated. ${ }^{2}$ Tissue injury in chronic inflammation is due to mediators of inflammation like prostaglandins and leukotrienes which attract polymormonuclear leukocytes at the site of inflammation. The major component prostaglandins that induce pain and inflammation are due to Phospholipase A2, converting phospholipids in the cell membrane into arachidonic acid, which is highly reactive and is rapidly metabolized by cyclooxygenase to prostaglandins. ${ }^{3}$ Alpinia galanga ethanolic extract from the family of Zingiberaceae with similar traditional medicinal use was subjected to evaluate scientifically in the current study for antinociceptive activity over chemical, neurogenic and inflammatory pain model followed by invitro cyclooxygenase assay and insilico computational analysis of certain chemical constituents of A. galanga by trial and error method for absorption, distribution, metabolism, elimination and properties (ADME) with Tumor necrosis factor - alpha docking studies. In silico computational analysis provides as a chance to identify the ideal chemical constituent with better pharmacokinetic profile for further research.

\section{METHODS}

\section{Animals}

Inbred male swiss albino mice weighing 20-25g were selected for the study. The animals were maintained on a $12 \mathrm{~h} / 12 \mathrm{~h}$ day/ night cycle with free access to food and water. Prior Institutional animal ethical committee approval was obtained for performing the experiments from Meenakshi Medical college and research institute.

\section{Drugs and chemicals}

The roots of the Alpinia galnga were collected from coimbatore district, Tamil nadu and the sample was authenticated by Dr Sasikala ethirajulu, (Assistant director - CSIR chennai). The roots of plant Alpinia galanga were shade dried and made into coarse powder. It was then passed through a 40 mesh sieve before extraction and the ethanolic extract from raw material was obtained (Chemeliods-Vijayawada) Various doses of Alpinia galanga were prepared as a fine suspension in $0.5 \%$ carboxy methyl cellulose (CMC) and administered per oral $30 \mathrm{~min}$ prior to any testing procedure. indomethacin $10 \mathrm{mg} / \mathrm{kg}$ and Morphine $2 \mathrm{mg} / \mathrm{kg}$ was used as a standard analgesic drug for comparison.

\section{Assessment of antinociceptive action}

The potential antinociceptive action of ethanolic extract of Alpinia galanga was assessed in chemical, neurogenic and inflammatory nociception in mice.

\section{Acetic acid induced abdominal constrictions}

This test was performed as described by Koster, et al. Mice were injected i.p with acetic acid $(0.6 \%)$ in a dose of 10 $\mathrm{ml} / \mathrm{kg}$ and the number of abdominal constrictions (writhings) was observed for the following $15 \mathrm{~min}$. Different doses of ethanolic extract of Alpinia galanga $(100-400 \mathrm{mg} / \mathrm{kg})$ were prepared as a fine suspension in $0.5 \% \mathrm{CMC}$ and given per oral $30 \mathrm{~min}$ before the testing procedure. Any reduction in the number of abdominal constrictions compared to vehicle treatment was considered as antinociceptive response. ${ }^{4}$

\section{Formalin assay}

Each mouse received $50 \mu \mathrm{l}$ of $1 \%$ formalin s.c in the left hind paw and time spent by the animal in licking / biting the hind paw was recorded for a period of $30 \mathrm{~min}$. The neurogenic phase of nociceptive response peaked from 0 $10 \mathrm{~min}$ and inflammatory phase from 10-30 min following formalin injection. A reduction in paw licking / biting response time exhibited by any treatment compared to vehicle was considered as antinociceptive response. Different doses of ethanolic extract of Alpinia galanga $(100-400 \mathrm{mg} / \mathrm{kg})$ were prepared as a fine suspension in $0.5 \% \mathrm{CMC}$ and given per oral $30 \mathrm{~min}$ before the testing procedure. $^{5}$

\section{In Silico computational analysis of pharmacokinetic and drug like features}

The molecules of Alpinia galanga ethanolic extract was considered for insilico evaluation for Absorption, distribution, metabolism and elimination(ADME) properties and TNF-alpha Docking studies by trial and error method using. The A. galanga extract identified molecules with published chemical structure includes Galanal B, Galanal A, $\beta$-Caryophyllene, $\alpha$-Humulene, $\beta$ Phyllandrene, Pomalidomide, Linalool, Limonene, 1, 8Cineole, Borneol, $\alpha$-Pinene, $\alpha$-Terpineol, Camphene, BPinene, 4-Terpineol, P-Cymene, Amrinone. ${ }^{6}$

\section{Hardware and Software}

The three Dimensional quantitative structure activity relationship analysis, molecular docking and dynamics of the molecules were carried out in centos linux platform version 5.0 or above installed in HPZ 800 workstation using Schrodinger LLC, Newyork, 2014 (4). ${ }^{7}$

\section{ADME predictions}

QikProp version 3.6 is used for insilico analysis of the hits on absorption, distribution, metabolism, excretion and toxicity for the hits and for the structurally optimized lead molecule in the virtual screening workflow protocol. ${ }^{8}$

The animal study was conducted during the period April 2012 to Jan 2013 at animal house facility Meenakshi medical college and research institute followed by insilico 
studies at Department of Bioinformatics, SVIMS University during March 2015 to August 2016.

\section{Statistical analysis}

The animal experimental results were analyzed using one way analysis of variance (ANOVA) followed by Dunnett's ' $t$ ' test for multiple comparison and paired ' $t$ ' test utilizing Graphpad Instat software version 3.1 (U.S.A). A probability value less than $5 \%$ was considered to be statistically significant. QikProp version 3.6 is used for insilico ADME analysis.

\section{RESULTS}

\section{Antinociceptive activity}

Writhing test - acetic acid induced abdominal constrictions in mice

The abdominal writhes in control group mice during the observation period is $37.33 \pm 3.55$ and there was a dose dependent inhibition of writhing in animal groups receiving Alpinia galanga $100 \mathrm{mg} / \mathrm{kg} \quad(30.00 \pm 3.74)$, $200 \mathrm{mg} / \mathrm{kg}(25.00 \pm 2.82)$ and $400 \mathrm{mg} / \mathrm{kg}(16.00 \pm 3.40)$. The number of writhes decreased significantly in all the test groups compared with control group $(\mathrm{P}<0.01)$. The percentage inhibition rate of Aspirin $(100 \mathrm{mg} / \mathrm{kg}$ ) was $82.15 \%$ compared to Alpinia galanga $(100 \mathrm{mg} / \mathrm{kg}) 19.63 \%$, $(200 \mathrm{mg} / \mathrm{kg}) 33.02 \%$ and $(400 \mathrm{mg} / \mathrm{kg}) 57.13 \%$.

Table 1: Acetic acid-induced writhes in mice.

\begin{tabular}{|c|c|c|c|}
\hline Group & n & $\begin{array}{l}\text { Number of } \\
\text { writhes }\end{array}$ & $\begin{array}{l}\text { Inhibition } \\
\text { rate }(\%)\end{array}$ \\
\hline $\begin{array}{l}\text { Control (Normal } \\
\text { Saline) }\end{array}$ & 6 & $37.33 \pm 3.55$ & --- \\
\hline $\begin{array}{l}\text { Standard (Morphine } \\
3 \mathrm{mg} / \mathrm{kg} \text { ) }\end{array}$ & 6 & $06.66 \pm 1.63$ & 82.15 \\
\hline $\begin{array}{l}\text { Test group I (AG } \\
100 \mathrm{mg} / \mathrm{kg})\end{array}$ & 6 & $30.00 \pm 3.74 *$ & 19.63 \\
\hline $\begin{array}{l}\text { Test group I (AG } \\
200 \mathrm{mg} / \mathrm{kg})\end{array}$ & 6 & $25.00 \pm 2.82 * *$ & 33.02 \\
\hline $\begin{array}{l}\text { Test group I (AG } \\
400 \mathrm{mg} / \mathrm{kg})\end{array}$ & 6 & $16.00 \pm 3.40 * *$ & 57.13 \\
\hline \multicolumn{4}{|c|}{ AG-Alpinia galanga, $\mathrm{n}=$ number, ${ }^{*} \mathrm{p}<0.05,{ }^{*} \mathrm{p}<0.005$} \\
\hline \multicolumn{4}{|c|}{$\begin{array}{l}\text { Inhibition rate }= \\
\qquad \frac{\text { Mean number of writhes(control) - Mean number of }}{\text { writhes (test) X } 100 \%}\end{array}$} \\
\hline
\end{tabular}

Mean number of writhes (control)

Table 2: Formalin induced nociception.

\begin{tabular}{|c|c|c|c|c|c|}
\hline \multirow{3}{*}{ Treatment } & \multirow{3}{*}{ Dose (mg/Kg) } & \multicolumn{4}{|c|}{ Number of Licks (Sec) } \\
\hline & & \multicolumn{2}{|c|}{ 0-5 min } & \multicolumn{2}{|l|}{ 20-30 min } \\
\hline & & Score of pain & Inhibition (\%) & Score of pain & Inhibition (\%) \\
\hline Vehicle (D.W) & $10 \mathrm{ml} / \mathrm{kg}$ & $49.83 \pm 7.60$ & --- & $122.50 \pm 6.44$ & --- \\
\hline Morphine & 2 & $22.50 \pm 2.58$ & 54.87 & $12.83 \pm 1.94$ & 89.53 \\
\hline Indomethosone & 10 & $38.66 \pm 3.98$ & 22.45 & $13.83 \pm 1.47$ & 88.71 \\
\hline AG Group -I & 100 & $41.00 \pm 4.33$ & 17.72 & $72.33 \pm 8.98$ & 40.96 \\
\hline AG Group-II & 200 & $34.00 \pm 3.57$ & 31.77 & $68.33 \pm 5.60$ & 44.22 \\
\hline AG Group-III & 400 & $34.83 \pm 4.30$ & 30.10 & $34.66 \pm 6.05$ & 71.70 \\
\hline
\end{tabular}

\section{Formalin induced nociception in mice}

Treatment with different doses of ethanolic extract of Alpinia galanga exhibited a significant reduction in paw licking / biting response time in both acute phase and chronic phases of formalin nociception when compared to vehicle treated group Alpinia galanga $400 \mathrm{mg} / \mathrm{kg}$ (71.70\%) had comparable percentage inhibition of nociception to standard group indomethacin $(88.71 \%)$. Thus, these compounds also appear to suppress the chronic phase of formalin response effectively.

\section{Inhibition rate $=$}

Mean score of pain (control)-Mean score of pain (test) $\mathrm{X}$

$$
100 \%
$$

Mean score of pain (control)

\section{DISCUSSION}

Alpinia galanga (Linn.) Willd is a native of Java and Sumatra mainly found in the Eastern Himalayas and Southwestern region and popularly known as 'Khulanjan' in Arabic and 'Galanga' in English. ${ }^{7}$ Alpinia galangal belongs to the same family of ginger (zingeberaceae) which was pharmacologically investigated and identified as a herbal medicinal product with documented pharmacological effect particularly in suppressing inflammatory mediators. ${ }^{9}$ There are few pharmacological studies on Alpinia galanga with established hypoglycemic activity, anthelmintic activity, antiulcer activity, aphrodisiac activity and antifungal activity. ${ }^{9-13}$ So far this species from zingeberaceae family has very few scientifically evaluated studies on analgesic and anti- 
inflammatory activities though commonly used in bone and joint pains in traditional medicine.

Table 3: Active extracts of Alpina galanga and control 2 AZ5 (307) against human TNF- $\alpha$.

\begin{tabular}{|ll|}
\hline Compound & Binding free energy (kcal/mol) \\
\hline Galanal B & -56.664 \\
\hline 2AZ5 (307) & -56.000 \\
\hline Galanal A & -53.479 \\
\hline$\beta$-Caryophyllene & -53.209 \\
\hline$\alpha$-Humulene & -50.091 \\
\hline$\beta$-Phyllandrene & -42.439 \\
\hline Pomalidomide & -42.088 \\
\hline Linalool & -41.953 \\
\hline Limonene & -41.904 \\
\hline $1,8-$ Cineole & -38.970 \\
\hline Borneol & -37.898 \\
\hline$\alpha$-Pinene & -37.699 \\
\hline$\alpha$-Terpineol & -36.739 \\
\hline Camphene & -36.589 \\
\hline B-Pinene & -35.157 \\
\hline 4-Terpineol & -35.014 \\
\hline Thalidomide & -34.175 \\
\hline Lenalidomide & -33.852 \\
\hline P-Cymene & -32.857 \\
\hline Amrinone & -31.041 \\
\hline 2AZ5 (307) - control TNF alpha Inhibitor \\
\end{tabular}

The ethanolic extract of Alpinia galanga when subjected to screening for analgesic activity by writhing test, tested doses exhibited a significant and dose dependent antinociceptive effect. The maximum inhibition of $57.13 \%$ was observed with the dose $400 \mathrm{mg} / \mathrm{kg}$ of extract which was comparable to the Non steroidal anti-inflammatory standard Aspirin with $71.44 \%$ inhibition Table 1. The study confirms that the extracts may act by peripheral antinociceptive mechanism.

The formalin induced nociception model was chosen to observe both neurogenic and inflammatory pain inhibition. Alpinia galanga alcoholic extract had maximal inhibition in neurogenic phase ranged from $17.12 \%$ to $30.10 \%$ and the inflammatory phase had maximal inhibition of $71.10 \%$ at the dose of $400 \mathrm{mg} / \mathrm{kg}$ comparable to $88.71 \%$ inhibition by indomethacin $10 \mathrm{mg} / \mathrm{kg}$ (Table 2). Thus, the inhibition of chronic phase of formalin nociception was greater than the acute phase indicating greater efficacy of the extract on inflammation. Earlier studies published reports of alcoholic extract of Alpinia galanga at dose of $400 \mathrm{mg} / \mathrm{kg}$ was more effective in suppressing nociception by hot plate test. The present study is in agreement with earlier reports and traditional claims for its rational use in pain.

The proceed further with the findings twenty two known compounds with chemical structure is challenged in silico with control 2AZ5 (307) against human TNF- $\alpha$. Among the screened compounds Galanal B exhibited higher stability with TNF- $\alpha$ receptor complex with free binding energy of -56.664 which is better than control 2AZ5 with binding energy -56.000 , followed by Galanal B, Galanal A, $\beta$-Caryophyllene and $\alpha$-Humulene exhibited -53.479, 53.209 and -53.209 respectively (Table 3 ).

Table 4: ADME properties of Galanal B and control compound (2AZ5-307).

\begin{tabular}{|c|c|c|c|}
\hline $\begin{array}{l}\text { Pharmacolo- } \\
\text { gical property }\end{array}$ & $\begin{array}{l}95 \% \text { FDA } \\
\text { approved } \\
\text { drugs range }\end{array}$ & $\begin{array}{l}\text { Galanal } \\
\text { B }\end{array}$ & $\begin{array}{l}\text { 2AZ5 } \\
(307)\end{array}$ \\
\hline $\begin{array}{l}\text { Drug like } \\
\text { property }\end{array}$ & $0-5$ & 0 & 2 \\
\hline $\begin{array}{l}\text { Molecular } \\
\text { weight of } \\
\text { molecule }\end{array}$ & $130-725$ & 308.46 & 547.619 \\
\hline Donor HB & $0-6$ & 3 & 0 \\
\hline Acceptor HB & $2-20$ & 5.1 & 6.5 \\
\hline $\begin{array}{l}\text { Predicted } \\
\text { octanol/water } \\
\text { partition } \\
\text { coefficient }\end{array}$ & $-2-6.5$ & 2.427 & $6.504 * *$ \\
\hline $\begin{array}{l}\text { Predicted } \\
\text { aqueous } \\
\text { solubility }\end{array}$ & $-6.5-0.5$ & -3.23 & $-6.751 * *$ \\
\hline $\begin{array}{l}\text { Predicted } \\
\text { apparent gut } \\
\text { blood } \\
\text { permeability in } \\
\mathrm{nm} / \mathrm{sec}\end{array}$ & $\begin{array}{l}<25 \text { poor, } \\
>500 \text { great }\end{array}$ & $\begin{array}{l}1050.153 \\
\text { (great) }\end{array}$ & $\begin{array}{l}209.049 * \\
*\end{array}$ \\
\hline $\begin{array}{l}\text { Predicted } \\
\text { brain/blood } \\
\text { partition } \\
\text { coefficient }\end{array}$ & $-3-1.2$ & -0.572 & 0.646 \\
\hline $\begin{array}{l}\text { Predicted skin } \\
\text { permeability }\end{array}$ & $-8-10$ & -2.824 & -4.521 \\
\hline $\begin{array}{l}\text { Predicted } \\
\text { primary } \\
\text { metabolites }\end{array}$ & $1-8$ & 4 & 7 \\
\hline $\begin{array}{l}\text { Human oral } \\
\text { absorption }\end{array}$ & $\begin{array}{l}1 \text { (low), } 2 \\
\text { (medium) or } \\
3 \text { (high) }\end{array}$ & 3 (high) & $\begin{array}{l}1 \\
(\text { low })^{* *}\end{array}$ \\
\hline $\begin{array}{l}\text { Percent human } \\
\text { Oral absorption }\end{array}$ & $\begin{array}{l}>80 \% \text { - high } \\
<25 \% \text { - poor }\end{array}$ & 95.23 & 80.638 \\
\hline $\begin{array}{l}\text { Lipinskis rule } \\
\text { of five }\end{array}$ & $\begin{array}{l}\operatorname{maximum} \text { is } \\
4\end{array}$ & 0 & 2 \\
\hline Rule of three & $\begin{array}{l}\text { maximum is } \\
3\end{array}$ & 0 & 2 \\
\hline
\end{tabular}

Further QikProp descriptors and ADME/T properties of Galanal B compared with control compound 2AZ5 revealed Galanal B predicted with more drug like property fitting within 95\% FDA approved drugs range such as desirable Molecular weight of molecule, Donor Hydrogen Bonds, Acceptor Hydrogen Bonds, Predicted octanol/water partition coefficient, Predicted aqueous solubility, Predicted apparent gut blood permeability in $\mathrm{nm} / \mathrm{sec}$, Predicted brain/blood partition coefficient, 
Predicted skin permeability, Predicted primary metabolites, Human Oral Absorption and Percent Human Oral Absorption (Table 4).

Lipinski's rule of five is a rule of thumb to evaluate drug likeness or determine if a chemical compound with a certain pharmacological or biological activity has properties that would make it a likely orally active drug in humans. The rule was formulated on the observation that most orally administered drugs are relatively small and moderately lipophilic molecules. ${ }^{6,14,15}$

Applying Lipinski rules on Galanal B, the compound satisfied the rules by exhibiting predicted molecular weight of $308.46 \quad(<500)$, octanol/water partition coefficient $2.427(<5), 3$ donor hydrogen bonds $(<5)$, acceptor hydrogen bonds $5.1(>5)$. Galanal B had a predicted aqueous solubility of -3.23 , gut blood permeability $1050 \mathrm{~nm} . \mathrm{sec}$ and 4 possible metabolites formation, which in turn predicts that galanal B is a compound of more likely to be orally administrable nature.

\section{CONCLUSION}

Alpinia galanga is a potent herb used by traditional medicine practioners for various inflammatory conditions. The present study scientifically validates its effectiveness in alleviating pain due to inflammation in animal nociceptive models and among 20 lead compounds investigated for anti-inflammatory property by insilico analysis, Galanal B is predicted as an ideal investigational new drug candidate for further development.

\section{ACKNOWLEDGEMENTS}

Authors would like to thank Department of Bioinformatics- SVIMS University and ChemeliodsVijayawada for the support.

Funding: No funding sources Conflict of interest: None declared

Ethical approval: The study was approved by the Institutional Animal Ethics Committee

\section{REFERENCES}

1. Arambewela LS, Arawwawala M, Owen NL, Jarvis B. Volatile oil of Alpinia galanga wild of Sri Lanka. J Essent Oil Res. 2007;19(5):455-6.

2. Grzanna R, Lindmark L, Frondoza CG. Ginger - An herbal medicinal product with broad antiinflammatory actions. J Med Food. 2005;8(2):125-32.
3. Higgs GA, Moncada S, Vane JR. Eicosanoids in inflammation. Ann Clin Res. 1984;16(5-6):287-99.

4. Koster R, Anderson M, De Beer A.J. Acetic acid for analgesic screening. Fed Proc. 1959;18:412-6.

5. Dubuisson D, Dennis SG. The formalin test: A quantitative study of the analgesic effects of morphine, meperidine and brain stem stimulation in rats and cats; Pain. 1977;4:161-74.

6. Arambewela Lakshmi Sri Lankan Medicinal plant Monograph and Analysis: Alpinia galanga Lakshmi Arambewela and Aravinda Wijesinghe.- Colombo: National Science Foundation,. Sri Lankan Medicinal Plants. 2006;10:36.

7. Schrödinger Release 2013-3: Maestro, version 9.6, Schrödinger, LLC, New York, NY, 2013.

8. Lipinski CA, Lombardo F, Dominy BW, Feeney PJ. Experimental and computational approaches to estimate solubility and permeability in drug discovery and development settings. Adv. Drug Deliv. Rev. March 2001;46(1-3):3-26.

9. Chopra RN, Chopra IC, Honda KL, Kapur LD. Alpinia galanga Wild. Chopra's Indigenous Drugs of India, U.N Dhur and Sons Pvt. Ltd., Calcutta. 1958:274-276.

10. Grzanna R, Lindmark L, Frondoza C. Ginger-A herbal medicinal product with broad anti-inflammatory actions. J. Med. Food. 2005;8(2):125-32.

11. Kaleysa RR, Raj RK. Screening of indigenous plants for anthelmintic action against human Ascari's lumbricoides Indian Journal of Physiology and Pharmacology. 1975;19(1):47-9.

12. Ogiso A, Kabayashi S. Antiulcer agents from Alpinia seeds Japan Kokai. 1974;74:36.

13. Puri HS. Vegetable aphrodisiac of India, Quart, J. Crude Drug Res. 1971;11(2):1742-8.

14. Haraguchi H, Kuwata Y, Inada K, Shingn K, Mujahara K, Nagao M, et al. Antifungal activity from Alpinia galanga on the competition for incorporation of unsaturated fatty acids in cell growth Planta Medica, 1996;62(4):308-13.

15. Lipinski CA. Lead- and drug-like compounds: the rule-of-five revolution. Drug Discovery Today: Technologies. 2004;1(4):337-41.

Cite this article as: Subash KR, Britto GF, Kumar KS, Umamaheshwari A, Konda VCR, Prakash BG. Analgesic activity of Alpinia galanga extract in mice models and TNF-alpha receptor computational docking analysis on its leads with pharmacokinetics prediction. Int J Basic Clin Pharmacol 2018;7:44650 . 